\title{
Gastric Adenocarcinoma in a Patient with X-Linked Agammaglobulinemia and HIV: Case Report and Review of the Literature
}

\author{
Joud Hajjar $^{1 *}$, Sana Hasan ${ }^{2}$, Lisa R. Forbes ${ }^{1}$, Vagish Hemmige ${ }^{2}$ and Jordan S. Orange ${ }^{1}$ \\ 'Section of Immunology, Allergy and Rheumatology, Department of Pediatrics, Texas Children's Hospital, Baylor College of \\ Medicine, Houston, TX, USA, ${ }^{2}$ Internal Medicine, Baylor College of Medicine, Houston, TX, USA
}

Keywords: X-linked agammaglobulinemia, Bruton's agammaglobulinemia, gastrointestinal malignancy, Helicobacter pylori, campylobacter, human immunodeficiency virus

\section{CLINICAL IMPLICATION}

Patients with primary immunodeficiency are at an increased risk of cancer. Our case and literature review indicate an association between $\mathrm{X}$-linked agammaglobulinemia and gastrointestinal malignancy and suggest that screening for gastrointestinal malignancy should occur for patients with $\mathrm{X}$-linked agammaglobulinemia and gastrointestinal symptoms, unexplained anemia, or atrophic gastritis.

$\mathrm{X}$-linked agammaglobulinemia (XLA) is an X-linked inherited disease caused by a germline mutation in the BTK gene leading to Bruton's tyrosine kinase deficiency, which results in the impaired development of B-lymphocytes and a subsequent lack of immunoglobulin production. Patients with XLA have an increased susceptibility to bacterial and viral infections, and multiple case reports have been published regarding an association between XLA and gastrointestinal (GI) malignancy.

Here, we describe a case of a 25-year-old man with XLA and HIV, who developed gastric adenocarcinoma. Previously reported cases of XLA and GI malignancy are also reviewed and summarized.

Alberta Health Services, Cane

*Correspondence: Joud Hajjar joud.hajjar@bcm.edu

Specialty section:

This article was submitted to Pediatric Immunology, a section of the journal Frontiers in Pediatrics

Received: 08 August 2016 Accepted: 05 September 2016 Published: 23 September 2016

Citation:

Hajjar J, Hasan S, Forbes LR,

Hemmige $V$ and Orange JS (2016) Gastric Adenocarcinoma in a Patient with X-Linked Agammaglobulinemia and HIV: Case Report and Review of the Literature.

Front. Pediatr. 4:100 doi: 10.3389/fped.2016.00100

\section{CASE REPORT}

A 25-year-old African-American man was referred to our center for continuous management of his XLA and HIV. At the age of 2 years, he started to develop recurrent infections, and based on a positive family history of XLA in a maternal uncle and several cousins, he was diagnosed with XLA and was started on intravenous immunoglobulin (IVIG) replacement since his diagnosis. Genetic testing was not initially done; however, recent genetic testing revealed a novel pathogenic variant in BTK c.307 C > T p.Gln103Ter (Q103X). His course was complicated by several sinopulmonary infections requiring hospitalization. Due to high-risk sexual behavior, he was screened for Human Immunodeficiency Virus (HIV) and at the age of 23 years and was found to be positive for HIV with high viral load; viral serology was never obtained due to his baseline agammaglobulinemia. $\mathrm{He}$ was asymptomatic and was started on, highly active antiretroviral therapy (HAART) (elvitegravir/ cobicistat/emtricitabine/tenofovir), which maintained his CD4 count $>1000$ cells $/ \mathrm{mm}^{3}$ and an undetectable viral load.

At the age of 24 years, he developed recurrent Campylobacter jejuni bacteremia and cellulitis of the leg, which was treated with meropenem for 4 weeks, subsequent episode was treated with a combination of intravenous meropenem and amikacin for 6 weeks. Suppressive doxycycline therapy was recommended, but the patient declined. Despite high-dose IVIG (700 mg/kg every 3 weeks), he continued to have immunoglobulin (Ig)G troughs $(400-560 \mathrm{mg} / \mathrm{dL})$. His stool culture, ova and parasite microscopic examination, and Giardia PCR were negative. 
The patient had chronic iron-deficiency anemia and positive occult blood in his stool; therefore, an esophagogastroduodenoscopy (EGD) and colonoscopy were performed. His colonoscopy with random biopsy was normal. However, EGD showed gastric inflammation with erosions and ulceration. A gastric biopsy showed poorly differentiated gastric adenocarcinoma, which was her2/neu negative. The stain for Helicobacter pylori was positive. From a clinical stand point, except for his recurrent cellulitis, the patient did not have any other symptoms such as abdominal pain, early satiety, or weight loss. His review of systems as well did not reveal any respiratory symptoms. Abdominal computed tomography (CT) was negative for enlarged lymph nodes. However, a $1.4-\mathrm{cm}$ arterially enhancing lesion in the left hepatic lobe was detected using abdominal and pelvic CT, with at least two adjacent sub-centimeter enhancing foci and two hepatic lesions. Abdominal magnetic resonance imaging characterized the larger lesion as hemangioma and the smaller lesions as cysts. Chest CT showed a 5-mm nodule, thought to be a granuloma. However, repeat CT scan of the lower lungs did not identify any nodules. His lungs otherwise were clear with no evidence of bronchiectasis or any other interstitial process. Genetic testing for $\mathrm{CDH} 1$ gene mutations, which are associated with hereditary diffuse Gastric cancer, was negative. He underwent subtotal gastrectomy, lymphadenectomy, and Roux-en-Y gastrojejunostomy. His post-operative pathology showed moderately poor differentiation of the adenocarcinoma with a signet ring component that was primarily mucosal with focal submucosal invasion, $0 / 20$ nodes, negative margins, and diffuse metaplasia as well as omentum negative. Staining was positive for $H$. pylori.

His final diagnosis was stage 1A gastric cancer. No further treatment was recommended, and he was placed under surveillance with no evidence of malignant recurrence. However, he subsequently developed one episode of $C$. jejuni bacteremia that was treated with intravenous antibiotics.

Esophagogastroduodenoscopy was performed 1 year later and was negative for any ulcerations or concerning signs of recurrence.

\section{DISCUSSION}

Patients infected with HIV are at increased risk of certain malignancies, including breast, anal, cervical, lung, colorectal, prostate, and hepatocellular carcinoma (1). However, gastric cancer has not been reported to have increased prevalence among HIV-infected patients. Our patient did not have an acquired immune deficiency syndrome (AIDS)-defining clinical condition. On the other hand, patients with antibody deficiency are at greater risk of lymphoma and GI malignancy (2). The increased incidence of stomach cancer in patients with common variable immunodeficiency disorders could be related to the high frequency of achlorhydria.

In our literature review of GI malignancy and XLA, we found a total of 15 cases of GI malignancy ( 5 cases of gastric adenocarcinoma, 9 cases of colorectal carcinoma, and 1 case of liver cancer) in addition to our reported case (Table 1).

The median age of male patients was 30 years (range, 7-40 years), indicating early onset of GI malignancy in patients

\begin{tabular}{|c|c|c|c|c|c|c|c|c|c|}
\hline Case & Country & $\begin{array}{l}\text { Presenting GI } \\
\text { symptoms }\end{array}$ & Histology & Anemia & $\begin{array}{l}\text { IgG }(\mathrm{mg} / \mathrm{dL}) \\
\text { on IVIG }\end{array}$ & Solid tumor & Stage & $\begin{array}{l}\text { Age } \\
\text { (years) }\end{array}$ & Outcome \\
\hline Adachi et al. (3) & Japan & $\begin{array}{l}\text { Diarrhea; frequent urge to } \\
\text { defecate }\end{array}$ & NA & NA & 95 & Colorectal & Local & 22 & Alive \\
\hline Sasi et al. (4) & $\begin{array}{l}\text { Saudi } \\
\text { Arabia }\end{array}$ & $\begin{array}{l}\text { Loss of appetite, weight } \\
\text { loss, diarrhea, right-sided } \\
\text { abdominal pain }\end{array}$ & NA & NA & NA & $\begin{array}{l}\text { Necrotizing } \\
\text { enterocolitis } \\
\text { of the colon }\end{array}$ & Mets & 10 & Dead \\
\hline $\begin{array}{l}\text { Bachmeyer } \\
\text { et al. (5) }\end{array}$ & France & Vomiting, dysphagia & $\begin{array}{l}\text { Chronic atrophic } \\
\text { gastritis, negative HP }\end{array}$ & NA & $235-450$ & Gastric & NA & 26 & NA \\
\hline $\begin{array}{l}\text { Staines Boone } \\
\text { et al. (6) }\end{array}$ & Mexico & $\begin{array}{l}\text { Phlebitis of the right leg, } \\
\text { weight loss }\end{array}$ & Gastric ulcer & Megaloblastic & 625 & Gastric & End & 30 & Dead \\
\hline Brosens et al. (7) & Netherlands & Malabsorption, weight loss & NA & NA & NA & Colorectal & Local & 45 & Alive \\
\hline Brosens et al. (7) & Netherlands & Weight loss & Positive HP & NA & NA & Colorectal & Local & 37 & Alive \\
\hline Chisuwa et al. (8) & Japan & NA & NA & NA & NA & Colorectal & NA & NA & NA \\
\hline Kinlen et al. (2) & UK & NA & NA & NA & NA & Gastric & End & 25 & Dead \\
\hline $\begin{array}{l}\text { Lackmann } \\
\text { et al. (9) }\end{array}$ & Germany & $\begin{array}{l}\text { Sensory deficit in the left } \\
\text { leg, B12 deficiency }\end{array}$ & $\begin{array}{l}\text { Negative HP; } \\
\text { atrophic gastritis }\end{array}$ & Megaloblastic & 172 & Gastric & Early & 15 & Alive \\
\hline Lavilla et al. (10) & Spain & $\begin{array}{l}\text { Vomiting, diarrhea, weight } \\
\text { loss }\end{array}$ & Atrophic gastritis & Megaloblastic & 479 & Gastric & Mets & 23 & Alive \\
\hline Our case & USA & Cellulitis of the leg & Positive HP & NA & $400-560$ & Gastric & $1 \mathrm{~A}$ & 25 & Alive \\
\hline Vajdic et al. (11) & Australia & NA & NA & NA & NA & Gastric & NA & 45 & NA \\
\hline $\begin{array}{l}\text { Van der Meer } \\
\text { et al. (12) }\end{array}$ & Netherlands & NA & NA & NA & NA & Colorectal & NA & 36 & Dead \\
\hline $\begin{array}{l}\text { Van der Meer } \\
\text { et al. (12) }\end{array}$ & Netherlands & $\begin{array}{l}\text { Abdominal distension, } \\
\text { cramps, diarrhea }\end{array}$ & Villous atrophy & Microcytic & 600 & Colorectal & NA & NA & Dead \\
\hline $\begin{array}{l}\text { Van der Meer } \\
\text { et al. (12) }\end{array}$ & Netherlands & $\begin{array}{l}\text { Diarrhea, abdominal } \\
\text { cramps, weight loss }\end{array}$ & NA & NA & Undetectable & Colorectal & NA & NA & Dead \\
\hline $\begin{array}{l}\text { Van der Meer } \\
\text { et al. (12) }\end{array}$ & Netherlands & $\begin{array}{l}\text { Diarrhea, abdominal } \\
\text { cramps }\end{array}$ & NA & NA & NA & Colorectal & NA & 36 & Dead \\
\hline
\end{tabular}

\footnotetext{
IgG, immunoglobulin G; IVIG, intravenous immunoglobulin; HP, Helicobacter pylori.
} 
with XLA. In the general population, the average age at diagnosis is 69 years, according to the American Cancer Society, and more than $80 \%$ of diagnosed cases of colorectal cancer occur in patients older than 55 years, according to a US task force.

Our patient had C. jejuni bacteremia, gastric inflammation, and H. pylori infection. He continued to have low IgG levels despite increasing the IgG replacement dose and frequency. We looked for a similar pattern in previously reported cases. Nine of the 16 patients had IgG levels $<700 \mathrm{mg} / \mathrm{dL}$, and 6 of these patients had levels $<500 \mathrm{mg} / \mathrm{dL}$, despite IVIG replacement. Two of the reported cases were positive for $H$. pylori, two were positive for C. jejuni bacteremia, two were infected with Giardia lamblia, and a majority had chronic atrophic gastritis. We hypothesized that chronic gastritis, with or without $H$. pylori infection, results in chronic inflammation, which could increase IgG catabolism or GI losses.

The anemia and positive occult blood in the present patient prompted the GI workup that led to his diagnosis. Three of the previously reported patients had megaloblastic anemia, and one patient had microcytic anemia. Chronic gastric inflammation can lead to achlorhydria, which in turn leads to megaloblastic anemia; this might be linked with gastric carcinoma in patients with common variable immunodeficiency (2) or XLA (6).

Finally, we reviewed the literature for the presenting signs and symptoms that support a diagnosis of GI malignancy; 10 of the 16 reported patients with XLA, who were diagnosed with GI malignancy, presented with weight loss or abdominal complaints such as diarrhea, a frequent urge to defecate, abdominal distension, cramping, and vomiting, which likely initiated the GI workup and led to an early diagnosis of GI malignancy. While there are many intestinal complications of antibody deficiencies, this one should be kept on the differential owing to its potential severity and treatability.

\section{REFERENCES}

1. Sigel K, Dubrow R, Silverberg M, Crothers K, Braithwaite S, Justice A. Cancer screening in patients infected with HIV. Curr HIV/AIDS Rep (2011) 8(3):142-52. doi:10.1007/s11904-011-0085-5

2. Kinlen LJ, Webster AD, Bird AG, Haile R, Peto J, Soothill JF, et al. Prospective study of cancer in patients with hypogammaglobulinaemia. Lancet (1985) 1(8423):263-6. doi:10.1016/S0140-6736(85)91037-2

3. Adachi Y, Mori M, Kido A, Shimono R, Suehiro T, Sugimachi K. Multiple colorectal neoplasms in a young adult with hypogammaglobulinemia. Report of a case. Dis Colon Rectum (1992) 35(2):197-200. doi:10.1007/ BF02050679

4. Sasi OA, Sathiapalan R, Rifai A, Tulbah AM, Al-Mehaidib A, Kofide A, et al. Colonic neuroendocrine carcinoma in a child. Pediatr Radiol (2005) 35(3):339-43. doi:10.1007/s00247-004-1319-0

5. Bachmeyer C, Monge M, Cazier A, Le Deist F, de Saint Basile G, Durandy A, et al. Gastric adenocarcinoma in a patient with X-linked agammaglobulinemia. Eur J Gastroenterol Hepatol (2000) 12(9):1033-5. doi:10.1097/00042737-200012090-00013

6. Staines Boone AT, Torres Martinez MG, Lopez-Herrera G, de Leija Portilla JO, Espinosa Padilla SE, Espinosa-Rosales FJ, et al. Gastric adenocarcinoma in the context of X-linked agammaglobulinemia: case report and review of the literature. JClin Immunol (2014) 34(2):134-7. doi:10.1007/s10875013-9971-5

7. Brosens LA, Tytgat KM, Morsink FH, Sinke RJ, Ten Berge IJ, Giardiello FM, et al. Multiple colorectal neoplasms in X-linked agammaglobulinemia. Clin Gastroenterol Hepatol (2008) 6(1):115-9. doi:10.1016/j.cgh.2007.08.019
In conclusion, our case and review of the previous literature indicate an increased risk of GI malignancy in patients with XLA. The fact that our patient was HIV infected could have increased his risk of malignancy in general, although medical literature does not suggest particularly increased the risk of gastric cancer among HIV-infected patients. We found the presence of $H$. pylori infection and megalobastic anemia to be associated with GI malignancy in XLA, and since those could be detected in noninvasive ways (via urea breath test and B12 levels, respectively) we suggest screening for those factors in all patients with XLA and if present, this should prompt physicians to initiate a workup for GI malignancy in those patients.

Finally, we would like to note that our patient developed gastric cancer at the age of 23 years, Lackmann et al. described a 10-year-old boy with XLA and gastric cancer (9), and all cases summarized in Table 1 were below the age of 40 years, pointing out to the early onset of gastric cancer in this pediatric-onset disease, and that long-term follow-up for such patients raise the awareness about complications to be sought in this disease. Further studies to evaluate the cost-effectiveness of early screening for GI malignancy in patients with XLA might be warranted.

\section{AUTHOR CONTRIBUTIONS}

Conception or design of the work: JH. Data collection: JH and SH. Data analysis and interpretation: JH. Drafting the article: $\mathrm{JH}$ and $\mathrm{SH}$. Critical revision of the article: JH, JO, and VH. Final approval of the version to be published: $\mathrm{JH}, \mathrm{SH}, \mathrm{LF}, \mathrm{VH}$, and $\mathrm{JO}$. Agreement to be accountable for all aspects of the work in ensuring that questions related to the accuracy or integrity of any part of the work are appropriately investigated and resolved: $\mathrm{JH}, \mathrm{SH}$, LF, VH, and JO.

8. Chisuwa H, Mori T, Fujimori K, Shigeno T, Maejima T. [Colorectal cancer in a young adult with X-linked agammaglobulinemia (XLA). Report of a case]. Nihon Shokakibyo Gakkai Zasshi (1999) 96(12):1392-5.

9. Lackmann GM, Wahn V,Poremba C, Niehues T. A teenager withX-linked agammaglobulinemia and vitamin B12 deficiency anemia. J Pediatr Gastroenterol Nutr (2005) 41(3):360-2. doi:10.1097/01.MPG.0000153003.59448.36

10. Lavilla P, Gil A, Rodriguez MC, Dupla ML, Pintado V, Fontan G. X-linked agammaglobulinemia and gastric adenocarcinoma. Cancer (1993) 72(5):1528-31. doi:10.1002/1097-0142(19930901)72:5<1528::AID-CNCR2820720506> 3.0.CO;2-V

11. Vajdic CM, Mao L, van Leeuwen MT, Kirkpatrick P, Grulich AE, Riminton S. Are antibody deficiency disorders associated with a narrower range of cancers than other forms of immunodeficiency? Blood (2010) 116(8):1228-34. doi:10.1182/blood-2010-03-272351

12. van der Meer JW, Weening RS, Schellekens PT, van Munster IP, Nagengast FM. Colorectal cancer in patients with X-linked agammaglobulinemia. Lancet (1993) 341(8858):1439-40. doi:10.1016/0140-6736(93)90883-I

Conflict of Interest Statement: The authors declare that the research was conducted in the absence of any commercial or financial relationships that could be construed as a potential conflict of interest.

Copyright (c) 2016 Hajjar, Hasan, Forbes, Hemmige and Orange. This is an openaccess article distributed under the terms of the Creative Commons Attribution License (CC BY). The use, distribution or reproduction in other forums is permitted, provided the original author(s) or licensor are credited and that the original publication in this journal is cited, in accordance with accepted academic practice. No use, distribution or reproduction is permitted which does not comply with these terms. 